\title{
Vapor-Liquid-Liquid Equilibrium Measurements and Modeling of the Methanethiol + Methane + Water Ternary System at 304, 334, and $364 \mathrm{~K}$
}

\author{
Awan, Javeed; Tsivintzelis, loannis; Valtz, Alain; Coquelet, Christophe; Kontogeorgis, Georgios
}

Published in:

Industrial \& Engineering Chemistry Research

Link to article, DOI:

10.1021/ie300888d

Publication date:

2012

Document Version

Publisher's PDF, also known as Version of record

Link back to DTU Orbit

Citation (APA):

Awan, J., Tsivintzelis, I., Valtz, A., Coquelet, C., \& Kontogeorgis, G. (2012). Vapor-Liquid-Liquid Equilibrium Measurements and Modeling of the Methanethiol + Methane + Water Ternary System at 304, 334, and $364 \mathrm{~K}$. Industrial \& Engineering Chemistry Research, 51(35), 11561-11564. https://doi.org/10.1021/ie300888d

\section{General rights}

Copyright and moral rights for the publications made accessible in the public portal are retained by the authors and/or other copyright owners and it is a condition of accessing publications that users recognise and abide by the legal requirements associated with these rights.

- Users may download and print one copy of any publication from the public portal for the purpose of private study or research.

- You may not further distribute the material or use it for any profit-making activity or commercial gain

- You may freely distribute the URL identifying the publication in the public portal 


\title{
Vapor-Liquid-Liquid Equilibrium Measurements and Modeling of the Methanethiol + Methane + Water Ternary System at 304, 334, and $364 \mathrm{~K}$
}

\author{
Javeed A. Awan, ${ }^{\dagger}$ Ioannis Tsivintzelis, ${ }^{\dagger}$ Alain Valtz, ${ }^{\dagger}$ Christophe Coquelet, ${ }^{\dagger}$ \\ and Georgios M. Kontogeorgis $* \dagger$ \\ ${ }^{\dagger}$ Center for Energy Resources Engineering (CERE), Department of Chemical and Biochemical Engineering, \\ Technical University of Denmark, Building 229, DK-2800 Kgs. Lyngby, Denmark \\ ${ }^{\ddagger}$ Mines ParisTech, CEP/TEP-Centre Énergétique et Procédés, 35 Rue Saint Honoré, 77305 Fontainebleau, France
}

\begin{abstract}
New vapor-liquid-liquid equilibrium (VLLE) data for methanethiol $\left(\mathrm{CH}_{3} \mathrm{SH}\right)+$ methane $\left(\mathrm{CH}_{4}\right)+$ water $\left(\mathrm{H}_{2} \mathrm{O}\right)$ have been obtained at three temperatures $(304,334$, and $364 \mathrm{~K}$ ) and pressures up to $9 \mathrm{MPa}$. A "static-analytical" method was used to perform all of the measurements. The objective was to provide experimental VLLE data for $\mathrm{CH}_{3} \mathrm{SH}$ with other natural gas contents at its crude form for which limited or no data are available in the open literature. Such kinds of data are required for the industrial modeling of sulfur emissions. It is observed from the experimental data that the solubility of $\mathrm{CH}_{4}$ in the aqueous and organic phases increases with an increase of the total system pressure and decreases with an increase of the temperature. However, the solubility of $\mathrm{CH}_{3} \mathrm{SH}$ in the aqueous and organic phases decreases slightly with an increase of the total system pressure and increases significantly with an increase of the temperature. The new VLLE data of this ternary system were compared with predictions of the cubic-plus-association equation of state. The model tends to underpredict the concentration of $\mathrm{CH}_{3} \mathrm{SH}$ in all phases, particularly the vapor phase.
\end{abstract}

\section{INTRODUCTION}

Methanethiol (methyl mercaptan) is a common component encountered in natural gas, synthesis gas, and various refinery process streams. Its typical concentration in the host gas stream can range from several parts per million to $50 \%$ by volume. ${ }^{1}$ Treatment processes need to be designed in order to remove not only $\mathrm{H}_{2} \mathrm{~S}$ and $\mathrm{CO}_{2}$ but also organic sulfur species like methanethiol and other prohibited compounds. This is necessary because regulations for environmental protection force the petroleum industry to decrease the sulfur content in various petroleum fluids. Furthermore, any thiols/mercaptans (RSH), carbonyl sulfide (COS), and carbon disulfide $\left(\mathrm{CS}_{2}\right)$ not absorbed from the sour gas through the amine purification units complicate the process scheme for downstream liquid treatment units. ${ }^{2}$ Knowledge of the phase equilibrium behavior and thermophysical properties of sulfur species mixtures with hydrocarbons/water is important to both process design and product specifications.

This work is a continuation of our previous work ${ }^{2-4}$ on the phase equilibrium measurements of systems containing thiols (mercaptans) with water and hydrocarbons. Such kinds of data are highly important for the design of new separation processes and the upgrade of existing processes. In this work, we provide new vapor-liquid-liquid equilibrium (VLLE) data for methanethiol $\left(\mathrm{CH}_{3} \mathrm{SH}\right)+$ methane $\left(\mathrm{CH}_{4}\right)+$ water $\left(\mathrm{H}_{2} \mathrm{O}\right)$ at three temperatures $(304,334$, and $364 \mathrm{~K})$ and pressures up to $9 \mathrm{MPa}$. The new VLLE data of these ternary systems were modeled with the cubic-plus-association (CPA) equation of state (EOS) using no adjustable parameters optimized in the ternary system data.

\section{EXPERIMENTAL SECTION}

Methanethiol ( $\mathrm{CH}_{3} \mathrm{SH}$, CAS Registry No. 74-93-1) was obtained from Aldrich and has a purity of 0.99 mole fraction. Methane $\left(\mathrm{CH}_{4}\right.$, CAS Registry No. 74-82-8) was obtained from Messer and has a purity of 0.998 mole fraction. Ultrapure water $\left(\mathrm{H}_{2} \mathrm{O}\right)$ was produced in the laboratory using commercial equipment (Millipore, model Direct-Q5). The electrical conductivity of Direct-Q water (ultrapure $\mathrm{H}_{2} \mathrm{O}$ ) is $5.495 \times 10^{-6} \mathrm{~S} \cdot \mathrm{m}^{-1}$ at $298.15 \mathrm{~K}$. No further purifications of the chemicals were made. The experimental work was carried at Mines ParisTech, where a "static-analytical" technique-based apparatus consisting of an equilibrium cell equipped with one moveable rapid online sampler injector was used. The equipment was the same as that used by Zehioua et al., ${ }^{5}$ and the procedure was identical with that of Coquelet et al. ${ }^{6}$ The liquid and vapor samples were analyzed using a gas chromatograph (Varian model CP-3800), equipped with a thermal conductivity detector (TCD) and a flame ionization detector (FID).

In all experiments at first, $\mathrm{H}_{2} \mathrm{O}$ was loaded into the equilibrium cell in the absence of air followed by $\mathrm{CH}_{3} \mathrm{SH}$. Then $\mathrm{CH}_{4}$ was added to reach the desired pressure. The required temperature was obtained by putting the cell into a thermoregulated oil bath. Once equilibrium was achieved; the vapor, aqueous (liquid), and organic (liquid) samples from the equilibrium cell were directly introduced to the gas chromatograph through an isothermally heated transfer line. Two $100 \Omega$ platinum

Received: April 8, 2012

Revised: June 26, 2012

Accepted: August 2, 2012

Published: August 2, 2012 
probes (Pt100) were used for temperature measurements: they were inserted inside thermowells drilled into the body of the equilibrium cell at two different levels and connected to an HP data acquisition unit. They were periodically calibrated against a $25 \Omega$ reference platinum resistance thermometer (Tinsley Precision Instruments, France). The resulting accuracy in the temperature measurements was estimated to be within $u(T, k=2)= \pm 0.04 \mathrm{~K}$. Pressures were measured by means of a Druck pressure transducer at $0.1-10 \mathrm{MPa}$, which was maintained at $353.15 \mathrm{~K}$. The pressure transducer was calibrated against a dead-weight pressure balance (Desgranges \& Huot 5202S, CP 0.3-40 MPa, Aubervilliers, France). Accuracies in the pressure measurements have been estimated to be within $u(P, k=2)= \pm 0.003 \mathrm{MPa}$. The gas chromatograph detectors were calibrated using chromatographic syringes with maximum mole number uncertainties of $2 \%$ in the TCD and $1.5 \%$ in the FID; thus, the maximum uncertainty as mole fraction is $u_{\max }=0.006$.

The gas chromatograph generated peaks of the individual components $\left[\mathrm{CH}_{4}\right.$ (FID), $\mathrm{CH}_{3} \mathrm{SH}$ (FID), and $\mathrm{H}_{2} \mathrm{O}$ (TCD)] at specific retention times, which were recorded using one RS-232 interface. The areas under such peaks correspond to the number of moles of the individual components, which came from the corresponding calibration. Each experimental data point was analyzed more than five times, until we got consistent values. The standard deviation on each experimental datum $\left(\sigma^{\mathrm{A}}\right)$ was calculated and is presented along with experimental data in Table 1. The method for calculation of the standard deviation on experimental data $\left(\sigma^{A}\right)$ is reported in our previous article. $^{2}$

\section{MODELING SECTION}

The experimental data were modeled using the CPA EOS. The CPA EOS is given in terms of the pressure as a sum of the SRK EOS and an associating contribution in eq 1 . The association term in this equation is a simpler but mathematically identical version of the term used in statistical association fluid theory. This form was proposed by Michelsen and Hendriks. ${ }^{7}$ The CPA EOS proposed by Kontogeorgis et al. ${ }^{8,9}$ can be expressed for mixtures in terms of pressure $P$ as

$$
\begin{aligned}
P= & \frac{R T}{V_{\mathrm{m}}-b}-\frac{\alpha(T)}{V_{\mathrm{m}}\left(V_{\mathrm{m}}+b\right)}-\frac{1}{2} \frac{R T}{V_{\mathrm{m}}}\left(1+\rho \frac{\partial \ln g}{\partial \rho}\right) \\
& \times \sum_{i} x_{i} \sum_{\mathrm{A}_{i}}\left(1-X_{\mathrm{A}_{i}}\right)
\end{aligned}
$$

where $V_{\mathrm{m}}$ is the molar volume. The key element of the association term is $X_{\mathrm{A}}$, which represents the fraction of sites (type A) on molecule $i$ not bonded with other active sites, while $x_{i}$ is the mole fraction of component $i . \alpha(T)$ and $b$ are the energy and covolume parameters of the SRK term. $X_{\mathrm{A}_{i}}$ is related to the association strength $\Delta_{\mathrm{A}_{\mathrm{B}} \mathrm{B}_{j}}$ between two sites belonging to two different molecules, e.g., site $\mathrm{A}$ on molecule $i$ and site $\mathrm{B}$ on molecule $j$; more details were presented in previous studies. ${ }^{8,9}$

The CPA EOS for thiols (mercaptan-containing systems) was described in our previous publications. ${ }^{3,4}$ The $4 \mathrm{C}$ association scheme was used for $\mathrm{H}_{2} \mathrm{O}$ according to the terminology from Huang and Radosz. ${ }^{10}$ Furthermore, $\mathrm{CH}_{3} \mathrm{SH}$ was considered to be a non-self-associating fluid but capable of cross associating with $\mathrm{H}_{2} \mathrm{O}$ (solvation). For this reason, one negative association site was assumed on every $\mathrm{CH}_{3} \mathrm{SH}$ molecule. The cross-association parameters were calculated using the

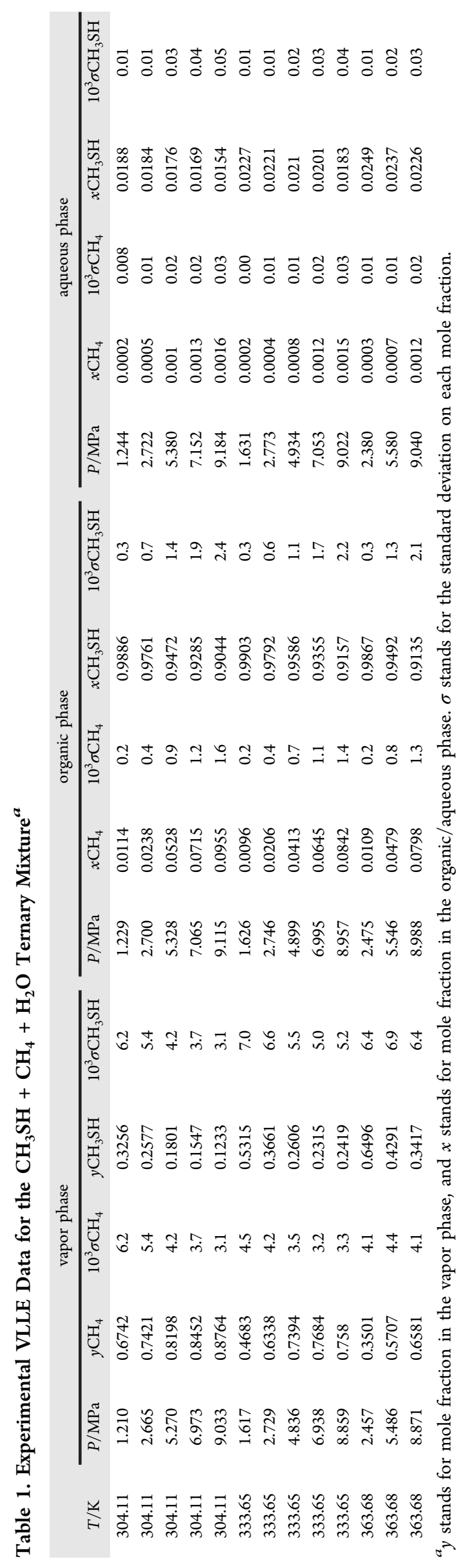


Table 2. CPA Pure-Component Parameters Used in This Work ${ }^{a}$

\begin{tabular}{|c|c|c|c|c|c|c|c|c|}
\hline component & $T_{\mathrm{c}} / \mathrm{K}$ & $b / \mathrm{L} \cdot \mathrm{mol}^{-1}$ & $\Gamma / \mathrm{K}$ & $c_{1}$ & $\varepsilon_{\mathrm{A}_{i} \mathrm{~B}_{i}} / \mathrm{bar} \cdot \mathrm{L}^{-1} \cdot \mathrm{mol}^{-1}$ & $\beta_{\mathrm{A}_{\mathrm{i}} \mathrm{B}_{i}}$ & $\% \mathrm{AAD}$ in $P^{\mathrm{Sat}}$ & $\% \mathrm{AAD}$ in $\rho^{\text {liq }}$ \\
\hline $\mathrm{CH}_{3} \mathrm{SH}^{3}$ & 469.95 & 0.0437 & 2266.2 & 0.8007 & & & 0.69 & 0.47 \\
\hline $\mathrm{CH}_{4}{ }^{12}$ & 190.56 & 0.0291 & 959.1 & 0.4472 & & & 0.35 & 1.97 \\
\hline $\mathrm{H}_{2} \mathrm{O}^{13}$ & 647.29 & 0.0145 & 1017.3 & 0.6736 & 166.55 & 0.0692 & 0.91 & 0.98 \\
\hline
\end{tabular}

${ }^{a}$ Average absolute deviation $(\mathrm{AAD})$ is defined as $\% \mathrm{ADD}=(1 / n) \sum_{i} \mathrm{I}\left(X_{i}^{\text {cal }}+X_{i}^{\text {exp }}\right) / X_{i}^{\text {exp }} \mid \times 100$, where $X$ stands for $P^{\mathrm{Sat}}$ or $\rho^{\text {liq }}$ and $n$ is the number of experimental data points, $\Gamma$ is defined as $a_{0} / R b$ where $a_{0}$ is the part of energy parameter of the EOS, which is defined using a Soave-type temperature dependency as: $a=a_{0}\left(1+\mathrm{C}_{1}[1-\sqrt{ }(\mathrm{Tr}])^{2}\right.$. $\mathrm{H}_{2} \mathrm{O}$ is modeled using the $4 \mathrm{C}$ association scheme.

modified CR-1 rule. ${ }^{13}$ The CPA EOS pure-component parameters $\left(b / \mathrm{L} \cdot \mathrm{mol}^{-1}, \Gamma / \mathrm{K}\right.$, and $\left.c_{1}\right)$ for $\mathrm{CH}_{3} \mathrm{SH}^{3}{ }^{3} \mathrm{CH}_{4},{ }^{12}$ and $\mathrm{H}_{2} \mathrm{O}^{13}$ are presented in Table 2. The $a_{0}$ parameter is tabulated as $\Gamma=a_{0} / R b$. The binary interaction parameters for $\mathrm{CH}_{4}-$ $\mathrm{H}_{2} \mathrm{O},{ }^{12} \mathrm{CH}_{4}-\mathrm{CH}_{3} \mathrm{SH},{ }^{4}$ and $\mathrm{CH}_{3} \mathrm{SH}-\mathrm{H}_{2} \mathrm{O}^{3}$ are presented in Table 3. The parameters were taken from the literature and applied to predict the VLLE of $\mathrm{CH}_{3} \mathrm{SH}+\mathrm{CH}_{4}+\mathrm{H}_{2} \mathrm{O}$.

Table 3. CPA Binary Interaction Parameters Used in This Work

\begin{tabular}{ccll}
\multicolumn{1}{c}{ mixture } & temperature range/K & \multicolumn{1}{c}{$k_{i j}$} & $\beta_{\text {cross }}$ \\
$\mathrm{CH}_{4}-\mathrm{H}_{2} \mathrm{O}^{12}$ & $303.1-363.1$ & 0.0098 & \\
$\mathrm{CH}_{4}-\mathrm{CH}_{3} \mathrm{SH}^{4}$ & $303.1-363.2$ & 0.079 & \\
$\mathrm{CH}_{3} \mathrm{SH}-\mathrm{H}_{2} \mathrm{O}^{3}$ & $303.1-363.3$ & 0.0089 & 0.0246
\end{tabular}

${ }^{a}$ Cross-association ${ }^{3}$ between $\mathrm{CH}_{3} \mathrm{SH}$ and $\mathrm{H}_{2} \mathrm{O}$ has been considered using the modified CR-1 rule. ${ }^{13}$

\section{RESULTS AND DISCUSSION}

In our previous work, ${ }^{3}$ we performed CPA calculations for Henry's law constant of methanethiol (MM) in $\mathrm{H}_{2} \mathrm{O}^{11}$ as a function of the temperature. It has been observed that, by taking into account the cross-associating effect in the $\mathrm{CH}_{3} \mathrm{SH}+$ $\mathrm{H}_{2} \mathrm{O}$ system, the CPA results were improved. The $\mathrm{CH}_{3} \mathrm{SH}+$ $\mathrm{H}_{2} \mathrm{O}$ system has also been studied and discussed in the literature by Gillespie and Wilson. ${ }^{11}$ The authors observed a drastic change in the solubility of $\mathrm{CH}_{3} \mathrm{SH}$ at higher temperature $(523-673 \mathrm{~K})$ compared to the lower temperature (313-423 K) data. We did not find any further data in the open literature for the ternary system investigated in this work, so a direct comparison is not possible. It is observed that the solubility of $\mathrm{CH}_{4}$ in the aqueous and organic phases increases with an increase in the total system pressure and decreases with an increase in the temperature. Furthermore, the solubility of $\mathrm{CH}_{3} \mathrm{SH}$ in the aqueous and organic phases decreases slightly with an increase of the pressure and increases significantly with an increase of the temperature. It has also been observed that the solubility of $\mathrm{CH}_{3} \mathrm{SH}$ is higher than that of $\mathrm{CH}_{4}$ in the aqueous phase in some cases. The solubilities of $\mathrm{H}_{2} \mathrm{O}$ in the organic and gas phases were not detected by gas chromatography because they were under the limit of detection. The detection limit of the gas chromatograph detectors in terms of mole numbers are as follows: $\mathrm{CH}_{3} \mathrm{SH}=9.78 \times 10^{-8}, \mathrm{H}_{2} \mathrm{O}=3.32$ $\times 10^{-6}$, and $\mathrm{CH}_{4}=4.51 \times 10^{-8}$. However, Gillespie and Wilson ${ }^{11}$ showed that the solubility of $\mathrm{H}_{2} \mathrm{O}$ in the gas phase varies inversely with the system pressure except at temperatures above $422 \mathrm{~K}$. These authors also conclude that the solubility of $\mathrm{H}_{2} \mathrm{O}$ in the liquid phase is slightly lower than the solubility in the vapor phase at three-phase saturation conditions.

The CPA EOS predictions for the VLLE of the $\mathrm{CH}_{3} \mathrm{SH}+$ $\mathrm{CH}_{4}+\mathrm{H}_{2} \mathrm{O}$ ternary system from 1 to $9 \mathrm{MPa}$ pressure at 304, 334 , and $364 \mathrm{~K}$ are shown in Figures $1-3$, respectively. It is

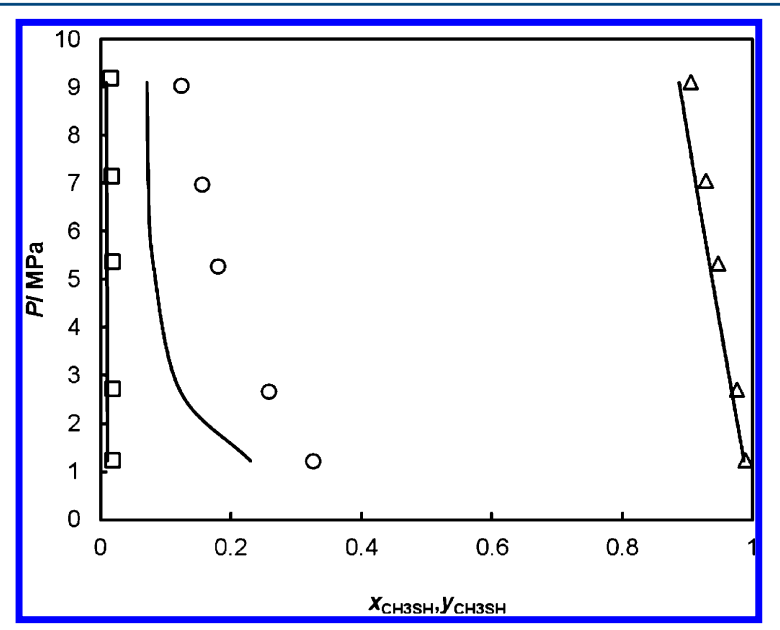

Figure 1. VLLE of the $\mathrm{CH}_{3} \mathrm{SH}+\mathrm{CH}_{4}+\mathrm{H}_{2} \mathrm{O}$ ternary system from 1 to $9 \mathrm{MPa}$ pressure at $304 \mathrm{~K}:(\triangle) \mathrm{CH}_{3} \mathrm{SH}$ in the organic phase; (O) $\mathrm{CH}_{3} \mathrm{SH}$ in the vapor phase; $(\square) \mathrm{CH}_{3} \mathrm{SH}$ in the aqueous phase. Solid lines: CPA EOS predictions.

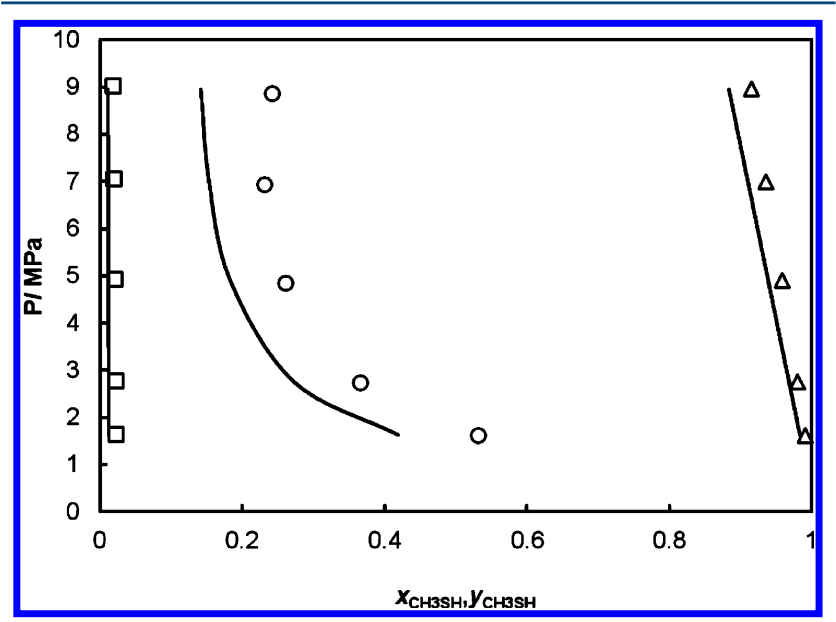

Figure 2. VLLE of the $\mathrm{CH}_{3} \mathrm{SH}+\mathrm{CH}_{4}+\mathrm{H}_{2} \mathrm{O}$ ternary system from 1 to $9 \mathrm{MPa}$ pressure at $334 \mathrm{~K}:(\triangle) \mathrm{CH}_{3} \mathrm{SH}$ in the organic phase; $(\mathrm{O})$ $\mathrm{CH}_{3} \mathrm{SH}$ in the vapor phase; $(\square) \mathrm{CH}_{3} \mathrm{SH}$ in the aqueous phase. Solid lines: CPA EOS predictions.

observed that the deviation between the experimental data and the CPA predictions is sometimes higher than $40 \%$. Especially, the CPA EOS predictions for the vapor-phase composition are rather poor. However, one should keep in mind that the CPA results are pure predictions because no parameters were adjusted to the experimental data. From this point of view, the CPA rather satisfactorily predicts the vapor-liquid and vaporliquid-liquid regions for the $\mathrm{CH}_{3} \mathrm{SH}+\mathrm{CH}_{4}+\mathrm{H}_{2} \mathrm{O}$ ternary system at $363.68 \mathrm{~K}$ and $8.966 \mathrm{MPa}$, as plotted in Figure 4, which shows that model can qualitatively predict the complicated three-phase equilibria of this system. 


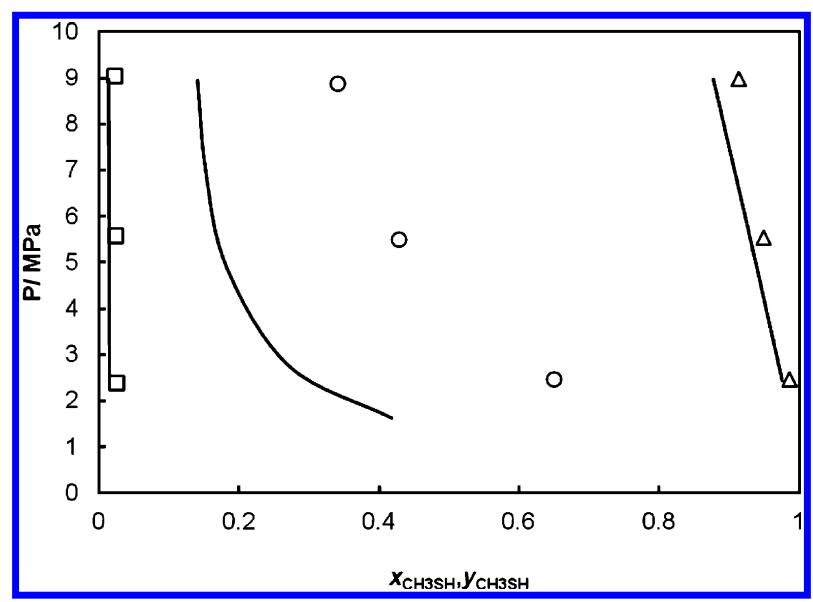

Figure 3. VLLE of the $\mathrm{CH}_{3} \mathrm{SH}+\mathrm{CH}_{4}+\mathrm{H}_{2} \mathrm{O}$ ternary system from 1 to $9 \mathrm{MPa}$ pressure at $364 \mathrm{~K}:(\triangle) \mathrm{CH}_{3} \mathrm{SH}$ in the organic phase; $(\mathrm{O})$ $\mathrm{CH}_{3} \mathrm{SH}$ in the vapor phase; $(\square) \mathrm{CH}_{3} \mathrm{SH}$ in the aqueous phase. Solid lines: CPA EOS predictions.

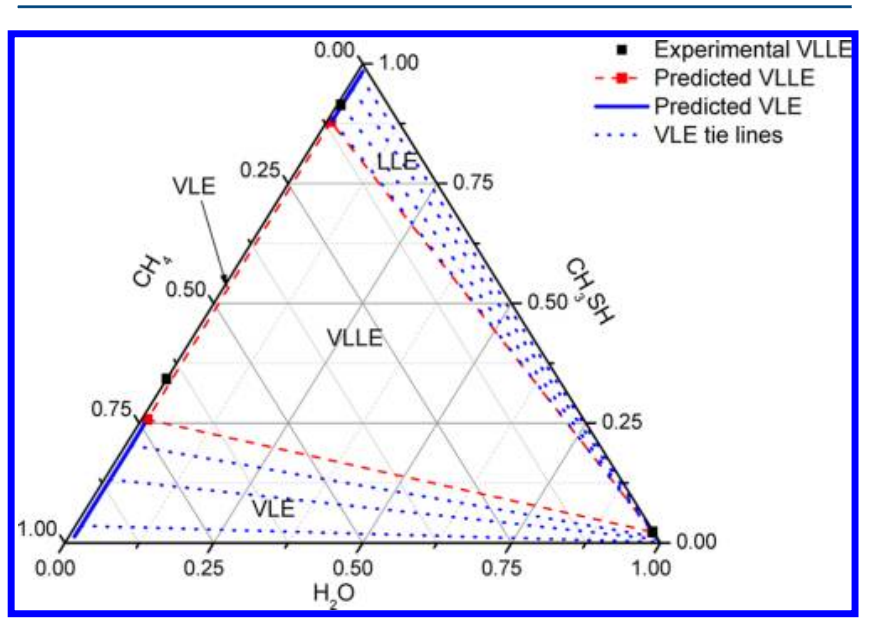

Figure 4. Phase diagram of the $\mathrm{CH}_{3} \mathrm{SH}+\mathrm{CH}_{4}+\mathrm{H}_{2} \mathrm{O}$ ternary system at $363.68 \mathrm{~K}$ and $8.966 \mathrm{MPa}$ : ( $\mathbf{\square})$ experimental VLLE data points; (red $\mathbf{\square}$ ) CPA EOS predictions. Dashed lines: predicted VLLE with CPA EOS. Solid lines: predicted VLE with CPA EOS. Dotted lines: predicted VLE tie lines with CPA EOS. Bold line: predicted VLE or LLE.

\section{CONCLUSION}

New VLLE data for $\mathrm{CH}_{3} \mathrm{SH}+\mathrm{CH}_{4}+\mathrm{H}_{2} \mathrm{O}$ were performed at three temperatures $(303,334$, and $364 \mathrm{~K})$ in a pressure range from 1 to $9 \mathrm{MPa}$. A "static-analytical" method was used successfully to perform all of the measurements. It is concluded that the gas solubility of $\mathrm{CH}_{3} \mathrm{SH}$ is higher than that of $\mathrm{CH}_{4}$ in the aqueous phase under similar temperature and pressure conditions. The CPA EOS has been applied for the representation of ternary systems containing $\mathrm{CH}_{3} \mathrm{SH}$. These modeling results for the ternary mixture of $\mathrm{CH}_{4}+\mathrm{CH}_{3} \mathrm{SH}+\mathrm{H}_{2} \mathrm{O}$ are satisfactory considering that they are predictions without the adjustment of any parameter to the ternary experimental data.

\section{AUTHOR INFORMATION}

\section{Corresponding Author}

*E-mail: gk@kt.dtu.dk. Phone: +45 45252859. Fax: +45 45882258.

Notes

The authors declare no competing financial interest.

\section{ACKNOWLEDGMENTS}

The authors gratefully acknowledge the Danish Council for Independent Research (Technology and Production Sciences) for the Postdoctoral research grant to Dr. J. A. Awan at CERE, DTU Chemical Engineering. We very much appreciate fruitful discussions with Prof. D. Richon (Mines ParisTech, France). The authors thank Statoil and Gassco (Norway), BP (UK, USA), TOTAL (France), and DONG Energy and Mærsk Oil and Gas (Denmark) for supporting the CPA EOS part of this work as part of the CHIGP project (Chemicals in Gas Processing).

\section{REFERENCES}

(1) Bymaster, A. Molecular Modeling the Microstructure and Phase Behavior of Bulk and Inhomogeneous Complex Fluids. Ph.D. Thesis, Rice University, Houston, TX, 2009.

(2) Awan, A. J.; Thomsen, K.; Coquelet, C.; Fosbøl, L. P.; Richon, D. Vapor-Liquid Equilibrium Measurements and Modeling of the Propyl Mercaptan + Methane + Water System. J. Chem. Eng. Data 2010, 55, $842-846$

(3) Awan, J. A.; Tsivintzelis, I.; Breil, M.; Coquelet, C.; Richon, D.; Kontogeorgis, G. M. Phase Equilibria of Mixtures Containing Organic Sulfur Species (OSS) and Water/Hydrocarbons: VLE Measurements and Modeling Using the Cubic-Plus-Association Equation of State. Ind. Eng. Chem. Res. 2010, 49 (210), 12718-12725.

(4) Awan, J. A.; Tsivintzelis, I.; Coquelet, C.; Kontogeorgis, G. M. Phase Equilibria on Three Binary Mixtures; Methyl mercaptan + Methane, Methyl mercaptan + Nitrogen and Methyl mercaptan + Carbon dioxide. J. Chem. Eng. Data 2012, 57, 896-901.

(5) Zehioua, R.; Coquelet, C.; Meniai, A. H.; Richon, D. Isothermal vapour-liquid equilibrium data of 1,1,1,2-tetrafluoroethane (R134a) + dimethylformamide (DMF) working fluids for absorption heat transformer. J. Chem. Eng. Data 2009, 55, 985-988.

(6) Coquelet, C.; Chareton, A.; Richon, D. Vapour-Liquid Equilibrium Measurements and Correlation of the Difluoromethane $(\mathrm{R} 32)+$ Propane (R290) + 1,1,1,2,3,3,3-Heptafluoropropane (R227ea) Ternary Mixture at Temperatures from 269.85 to 328.35 K. Fluid Phase Equilib. 2004, 218, 209-214.

(7) Michelsen, M. L.; Hendriks, E. M. Physical properties from association models. Fluid Phase Equilib. 2001, 180, 165-174.

(8) Kontogeorgis, G. M.; Michelsen, M. L.; Folas, G. K.; Derawi, S.; Solms, N. V.; Stenby, E. H. Ten Years with the CPA (Cubic-PlusAssociation) Equation of State. Part-I. Pure Compounds and SelfAssociating Systems. Ind. Eng. Chem. Res. 2006, 45, 4855-4868.

(9) Kontogeorgis, G. M.; Voutsas, E. C.; Yakoumis, I. V.; Tassios, D. P. An Equation of State for Associating Fluids. Ind. Eng. Chem. Res. 1996, 35, 4310-4318.

(10) Huang, S. H.; Radosz, M. Equation of State for Small, Large, Polydisperse and Associating Molecules. Ind. Eng. Chem. Res. 1990, 29, 2284-2294.

(11) Gillespie, P. C.; Wilson, G. M. Sulfur Compounds and Water V-L-E and Mutual Solubility MESH- $\mathrm{H}_{2} \mathrm{O} ; \mathrm{ETSH}-\mathrm{H}_{2} \mathrm{O} ; \mathrm{CS}_{2}-$ $\mathrm{H}_{2} \mathrm{O}$; and COS $-\mathrm{H}_{2} \mathrm{O}$. GPA Research Report RR-78; Gas Processors Association: Tulsa, OK, 1984.

(12) Tsivintzelis, I.; Kontogeorgis, G. M.; Michelsen, M. L.; Stenby, E. H. Modeling Phase Equilibria for Acid Gas Mixtures Using the CPA Equation of State. I. Mixtures with $\mathrm{H}_{2} \mathrm{~S}$. AIChE J. 2010, 56 (11), 2965-2982.

(13) Kontogeorgis, G. M.; Folas, G. K.; Muro-Suňé, N.; Roca, L, F.; Michelsen, M, L. Solvation phenomena in association theories with applications to oil and gas and chemical industries. Rev. Inst. Fr. Pet. 2008, 63, 305-319.

(14) Kontogeorgis, G. M.; Yakoumis, I. V.; Meijer, H.; Hendriks, E.; Moorwood, T. Multicomponent phase equilibrium calculations for water-methanol-alkane mixtures. Fluid Phase Equilib. 1999, 201, $158-160$. 